UDC: 339.924

\title{
TRADE AND COMPETITIVE COOPERATION OF THE EU WITH THE MAJOR INTERNATIONAL INTEGRATION GROUPINGS
}

\section{ТОРГОВО-ЕКОНОМІЧНА ВЗАЕМОДІЯ ЄС 3 НАЙБІЛЬШИМИ ІНТЕГРАЦЙНИМИ ОБ'ЄДНАННЯМИ}

\section{ТОРГОВО-ЭКОНОМИЧЕСКОЕ ВЗАИМОДЕЙСТВИЕ ЕС С КРУПНЕЙШИМИ ИНТЕГРАЦИОННЫМИ ОБЪЕДИНЕНИЯМИ}

\author{
Zayats O. I.
}

PhD. in International Economic Relations, Associate Professor at the Department of International Economic Relations, Uzhorod National University. E-mail: olena.zayats@uzhnu.edu.ua

\section{Заяць О. I.}

Кандидат економічних наук, доцент кафедри міжнародних економічних відносин Ужгородського національного університету. E-mail: olena.zayats@uzhnu.edu.ua

Заяц Е. И.

Кандидат экономических наук, доцент кафедры международных экономических отношений Ужгородского национального университета. E-mail: olena.zayats@uzhnu.edu.ua

\begin{abstract}
Absract. The article examines the current interaction, convergence and the state of formalization of trade and competitive cooperation between the largest international integration groupings, namely, negotiating the free trade area between them and determining the possible prospects for the development of transregional integration. The aim of the study is to analyze the main trends of free trade zones and agreements between the European Union (EU), United States-Mexico-Canada Agreement (USMCA), Association of Southeast Asian Nations (ASEAN), South American economic organization (MERCOSUR), the impact of transregional integration on trade and investment activities of Member States and integration groupings in general. The analysis of current trends has indicated the strengthening of the momentum of the negotiations on free trade zones between international integration groupings and the establishment of the major global trend: the number and types of agreements on trade and economic cooperation not only between countries, but also between interstate integration groupings are growing, new free trade zones are being announced, and the range of concepts regarding competitive advantages is being extended. It has been determined that trade and competitive interaction of the global economy creates a stable platform for building up both economic and competitive force, which leads to global economic development and enhances hypercompetition. It has been proved that trade and competitive convergence of interstate integration groupings leads to new forms and mechanisms of activities organization and as a result, the prospects for the consolidation of free trade zones are emerging. Thus, the competitive position of international integration associations in the global economy is being strengthened due to active development of economic and trade cooperation, not only within the grouping of Member States, but also in the parallel process of interaction with non-Member States and with international integration groupings.
\end{abstract}

Key words: transregional integration, EU, USMCA, ASEAN, MERCOSUR.

Анотація. Стаття присвячена дослідженню сучасної взаємодії, зближення та стану формалізації торговельно-конкурентного співробітництва між найбільшими міжнародними інтеграційними угрупуваннями, а саме ведення переговорів про створення зони вільної торгівлі між ними та визначення можливих перспектив розвитку трансрегіональної інтеграції. 
Метою даного дослідження $є$ аналіз основних тенденції створення зон вільної торгівлі та домовленостей між Свропейським союзом (СС), зоною вільної торгівлі США-Канада-Мексика (ЮСМКА), Асоціацією країн Південно-Східної Азії (АСЕАН), спільним ринком країн Південної Америки (МЕРКОСУР), вплив трансрегіональної інтеграції на торговельну та інвестиційну діяльність країн-членів та інтеграційних об'єднань в цілому. Аналіз сучасних тенденцій продемонстрував посилення динаміки переговорів щодо створення зон вільної торгівлі між міжнародними інтеграційними союзами та утворення найважливішого глобального тренду: зростає кількісна i видова різноманітність домовленостей про торговельно-економічну взаємодію не тільки між країнами, але й між міждержавними інтеграційними угрупуваннями, анонсуються нові зони вільної торгівлі, розширюється коло концепцій створення конкурентних переваг. Було визначено, що торговельно-конкурентна взаємодія суб'єктів глобального господарства створює стабільну платформу для нарощення як економічної, так і конкурентної сили, що зумовлює загальносвітовий економічний розвиток та сприяє посиленню гіперконкуренції. Обгрунтовано, що торговельно-конкурентне зближення міждержавних інтеграційних об’єднань призводить до формування нових форм і механізму організації діяльності і як наслідок вимальовуються перспективи укрупнення зон вільної торгівлі. Таким чином, конкурентні позиції міжнародних інтеграційних об'єднань у глобальному господарстві зміцюються завдяки активному розвитку економіко-торговельної співпраці, не тільки у межах об'єднання між країнами-членами, але і у паралельному процесі взаємодії з країнами, які не є членами та з міжнародними інтеграційними союзами.

Ключові слова: трансрегіональна інтеграція, СС, ЮСМКА, АСЕАН, МЕРКОСУР.

Аннотация. Статья посвящена исследованию современного взаимодействия, сближения и состояния формализации торгово-конкурентного сотрудничества между крупнейшими международными интеграционными группировками, а именно ведение переговоров о создании зон свободной торговли между ними и определение возможных перспектив развития трансрегиональной интеграции. Целью данного исследования являетса анализ основных тенденций создания зон свободной торговли и договоренностей между Европейским союзом (ЕС), зоной свободной торговли США-Мексика-Канада (ЮСМКА), Ассоциацией государств Юго-Восточной Азии (АСЕАН), общим рынком стран Южной Америки (МЕРКОСУР), влияние трансрегиональной интеграции на торговую и инвестиционную деятельность странчленов и интеграционных объединений в целом. Анализ современных тенденций продемонстрировал усиление динамики переговоров о создании зон свободной торговли между международными интеграционными союзами и образования важнейшего глобального тренда: растет количественная и видовое разнообразие договоренностей о торговоэкономическом взаимодействии не только между странами но и между межгосударственными интеграционными группировками, анонсируются новые зоны свободной торговли, расширяется круг концепций создания конкурентных преимуществ. Было определено, что торгово-конкурентное взаимодействие субъектов глобального хозяйства создает стабильную платформу для наращивания как экономической, так и конкурентной силы, что приводит к общемировому экономическому развитию и способствует усилению гиперконкуренции. Обосновано, что торгово-конкурентное сближение межгосударственных интеграционных объединений приводит к формированию новых форм и механизмов организации деятельности и как следствие вырисовываютса перспективы укрупнения зон свободной торговли. Таким образом, конкурентные позиции межгосударственных интеграционных объединений в глобальном хозяйстве усиливаются благодаря активному развитию экономико-торгового сотрудничества, не только в рамках объединения между странами-членами, но и в паралельном процесе взаимодействия со странами, не являющимися членами и с международными интеграционными союзами.

Ключевые слова: трансрегиональная интеграция, ЕС, ЮСМКА, АСЕАН, МЕРКОСУР. 
Introduction. Within today's globalized world economy, almost all interstate integration groupings face uncertainty regarding cooperation with non-Member States and other integration groupings. While in recent years the economic integration of countries has developed intensively, today the formalization of cooperation between interstate integration groupings, namely the negotiation of a free trade zone between them is the phenomenon of great importance. The position of any integration grouping proved to be determined not only by the internal potential and interaction between the Member States of the grouping, but also by the degree of economic and competitive cooperation, since it becomes apparent that the economies of the Member States of the integration grouping cannot be restricted by the grouping, but must develop their economic and competitive relations.

Analysis of latest researches and publications. The theoretical definition of transregionalization is comprehensively presented in the works by Hänngi, H., Roloff, R., \& Rüland, J. [Hänngi, H., Roloff, R., \& Rüland, J., 2006], which prove that a broad understanding of transregionalism includes both relations between regional groupings and regional groups and between groupings and third countries. Baert, F., Scaramagli, T. \& Soderbaum, F. in their work [Baert, F., Scaramagli, T. \& Soderbaum, F., 2014] highlight the existence of two integration groupings as a necessary precondition for the establishment of classical transregional relations. Lay, Y. \& Lopez, L. in their study [Lay, Y. \& Lopez, L., 2008], identify types of transregional interaction. The issues of free trade zones and trade and competitive cooperation of international integration groupings were covered in the works by L. Ghiotto \& J. Echaide [L. Ghiotto \& J. Echaide, 2019], M. Baltensperger \& U. Dadush [M. Baltensperger \& U. Dadush, 2019], S. Michalopoulos [S. Michalopoulos, 2019], C. Felter, D. Renwick \& A. Chatzky [C. Felter, D. Renwick \& A. Chatzky, 2019], S. Manservisi \& F. Fontan, 2019 [S. Manservisi \& F. Fontan, 2019], M. Schneider-Petsinger [M. Schneider-Petsinger, 2019], E. Wragg [E. Wragg, 2020].

The purpose of research is to study the interaction and convergence of interstate integration groupings in terms of trade and competition and closely examine and analyze the negotiation processes, as well as agreements between the largest interstate integration groupings: USMCA, EU, ASEAN and MERCOSUR.

The main results of the research. The competitive status of interstate integration groupings in the international arena is ensured not only by using the benefits of intra-regional cooperation, but also by deepening trade and economic ties with other actors in the global economy, including international integration associations. Current realities show a tendency to strengthening the momentum of the negotiations on free trade zones between international integration groupings and the establishment of the major global trend: the number and types of agreements on trade and economic cooperation not only between countries, but also between interstate integration groupings are growing, new free trade zones are being announced, and the range of concepts regarding competitive advantages is being extended. Trade and competition between actors of global economy creates a stable platform for building up both economic and competitive forces, which leads to global economic development and enhances hypercompetition.

The process of interaction between groupings is inherently a new phenomenon, so it deserves a detailed analysis. Negotiations on the free trade zone are actually at the stage of arrangement of all major trade and competitive blocs. In other words, today there is a transformation of foreign economic activity in terms of the processes of international economic integration and disintegration. Thus, the rapid growth of "inter-grouping ties" within the framework of the recent interaction of the largest interstate integration groupings, is explained by the search for competitive advantages.

In June 2019, after twenty years of negotiations between the European Union and the countries of the South American Common Market (MERCOSUR), the agreement was reached to establish an ambitious, balanced and comprehensive free trade zone. The agreement will partially repeal most of the current tariffs on exports from the EU to the MERCOSUR countries. However, there is still considerable uncertainty about the next steps [L. Ghiotto \& J. Echaide, 2019].

"The agreement will create free trade zone for 780 million people, will bring the two continents in a spirit of cooperation and openness. We agreed with our colleagues and allies with 
whom we have strong historical links and with whom we have successful cooperation in other areas. The agreement will save European companies over $€ 4$ billion in duties", Commissioner for Trade Cecilia Malmström said [European Commission, 2019].

Thus, in our opinion, the free trade agreement between the EU and MERCOSUR will have positive economic effects for both groupings, especially given the growing trade tensions in the global market. In terms of the MERCOSUR Member States, the aforementioned free trade zone will contribute to the diversification of trade and competition relations and reduce their dependence on USMCA Member States, significantly build up competitive force and enhance international prestige of the grouping, not to mention the markets for products (it will allow Argentina and Brazil to strengthen their integration into global value chains). The European Union is one of the largest partners for MERCOSUR in trade and investment. Trade with EU Member States accounts for $17.1 \%$ of the bloc's total trade (see Figure 1).

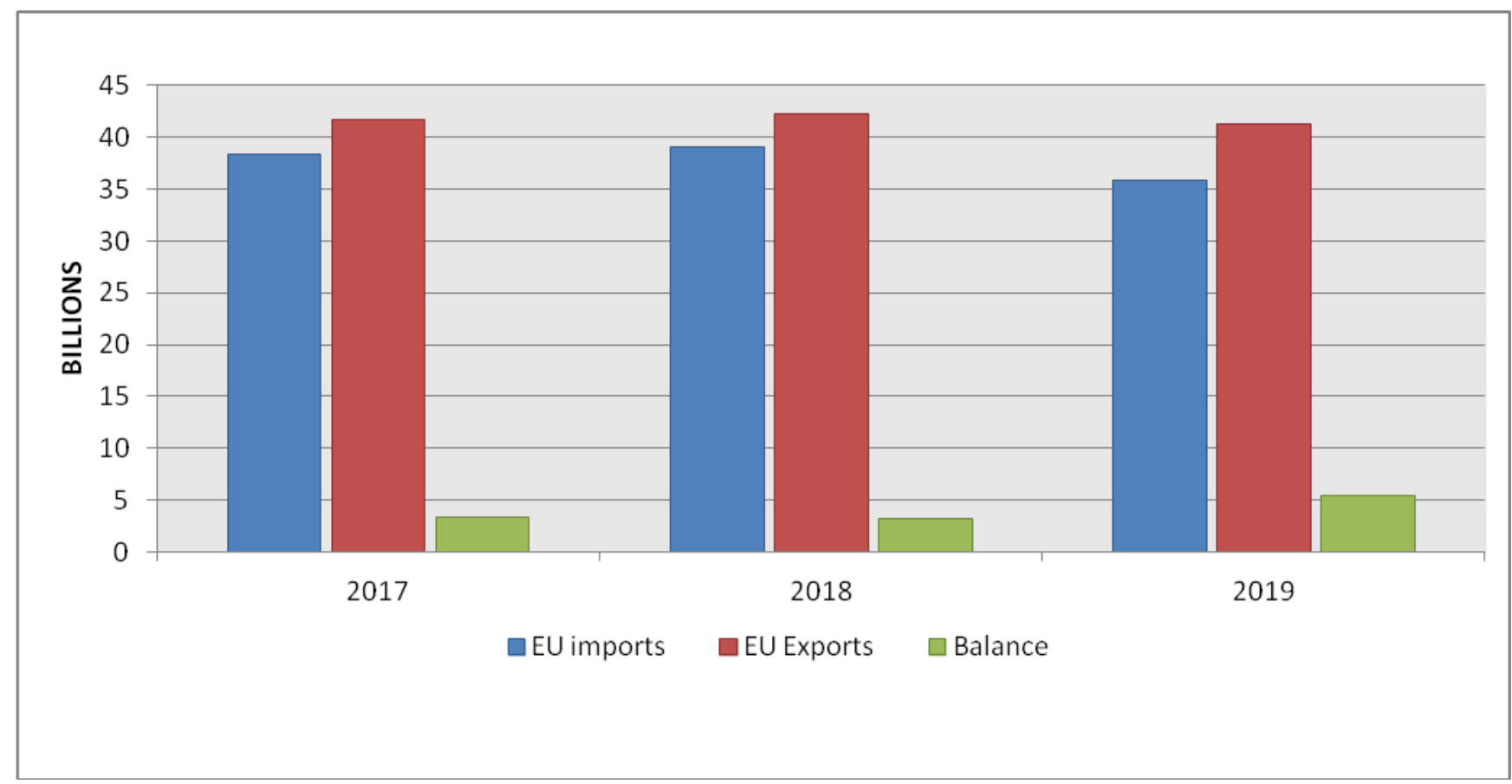

Figure 1. EU-MERCOSUR: trade in goods

Source: [European Commission, 2020]

In 2019, EU exports to MERCOSUR Member States amounted to $€ 41$ billion (vehicles, transport equipment, chemicals and pharmaceuticals), while MERCOSUR exports to the EU was $€ 35.9$ billion (agricultural products such as food, beverages and tobacco; plant products, including soy and coffee and animal products). The European Union exported $€ 21$ billion in services to MERCOSUR, while MERCOSUR exported $€ 10$ million in services to the EU in 2018 . The EU is the largest foreign investor in the region, and accumulated investment capital increased from $€ 130$ billion in 2000, when negotiations had just begun, to $€ 365$ billion in 2017. MERCOSUR is the EU's main investor, with $€ 52$ billion in 2017 [European Commission, 2020]. It should be noted that the mutual trade between these two integration groupings developed dynamically. Viewed the EUMERCOSUR export as a whole, from 1998 to 2018 it increased 1.9 times, and MERCOSUR-EU export increased 2.3 times (see Table 1). 
Table 1

EU-Mercosur trade over time in \$ billions

\begin{tabular}{|l|c|c|c|}
\hline EU exports to Mercosur & $\mathbf{1 9 9 8}$ & $\mathbf{2 0 0 8}$ & $\mathbf{2 0 1 8}$ \\
\hline Agricultural, forestry, and fishery & 0.2 & 0.2 & 0.5 \\
\hline Mineral commodities & 0.1 & 1.7 & 3.5 \\
\hline Manufacturing & 25.9 & 44.6 & 44.7 \\
\hline Total exports & $\mathbf{2 6 . 1}$ & $\mathbf{4 6 . 5}$ & $\mathbf{4 8 . 6}$ \\
\hline Mercosur exports to EU & $\mathbf{1 9 9 8}$ & $\mathbf{2 0 0 8}$ & $\mathbf{2 0 1 8}$ \\
\hline Agricultural, forestry, and fishery & 5.3 & 16.0 & 8.0 \\
\hline Mineral commodities & 1.9 & 12.9 & 5.7 \\
\hline Manufacturing & 11.9 & 44.2 & 30.0 \\
\hline Total exports & $\mathbf{1 9 . 1}$ & $\mathbf{7 3 . 1}$ & $\mathbf{4 3 . 7}$ \\
\hline
\end{tabular}

Source: [M. Baltensperger \& U. Dadush, 2019]

The interest of the European Union is based not only on the attractive commercial opportunities of MERCOSUR, but also on the restoration of historical relations with the states of South America and the possibility of creating another multipolar world. However, some experts express concern about this agreement, which is mainly based on the following issues: possible economic losses for the EU agriculture; Brazil's stance on environmental protection, since tariff reductions will affect deforestation (Amazon fire outbreak in 2019).

"The trade deal recently reached between the EU and MERCOSUR countries is devastating for European farmers", Pekka Pesonen, Secretary-General of the EU farmers and cooperatives' association said [S. Michalopoulos, 2019]. In general, European farmers strongly criticize this agreement and emphasize that lowering tariffs and increasing quotas on agricultural products such as beef and chicken threaten their business [EU-MERCOSUR, 2019]. Analysts warn that interest groups could once again delay progress [C. Felter, D. Renwick \& A. Chatzky, 2019]. Thus, it is evident that the problems of interaction and behavior patterns of interstate integration groupings in global competitive space depend on many factors.

At the heart of trade and competitive cooperation between the European Union and the Association of Southeast Asian Nations is the start of the dialogue in 1977, which was officially institutionalized in 1980. However, relations between the EU and ASEAN changed and expanded, and in January 2019, at the 22nd ASEAN-EU Ministerial Meeting, a joint statement was approved, where it was agreed to upgrade trade and competition relations. The Foreign Ministers reaffirmed their bilateral interest in strengthening relations and enhancing cooperation of mutual importance [ASEAN Secretariat's, 2020].

Some of the main tools of the dialogue between the European Union and ASEAN are: Enhanced Regional EU-ASEAN Dialogue Instrument for 2016-2024 (E-READI), whose total budget reaches $€ 20$ million; Enhanced ASEAN Regional Integration Support from EU 2017-2022 (ARISE-Plus), whose total budget accounts to €41 million; EU Support to Higher Education in ASEAN Region 2019/2021 (EU SHARE), with total budget $€ 10.3$ million; Biodiversity Conservation and Management of Protected Areas ASEAN 2016-2021 (BCAMP), with total budget of $€ 10$ million. It is undeniable that such instruments strengthen the cooperation between these integration groupings, and the interaction between the European Union and the Association of Southeast Asian Nations is intensive.

As of 2020, negotiations on the establishment of a joint EU-ASEAN free trade zone occur mainly in the form of bilateral negotiations between the Member States of the Association of Southeast Asian Nations and the European Union. These bilateral trade and investment negotiations serve as the foundation for the future free trade agreement between the mentioned integration groupings. ASEAN Member States are more independent than the EU Member States, as they can, 
for example, agree separately to create a free trade zone with any actors in the global economy, both with other states and with interstate integration groupings, while within the European Union an agreement on the establishment of a free trade zone is possible only in the form of the EU plus any actor of the global economy. The European Union is negotiating with all ASEAN Member States [S. Manservisi \& F. Fontan, 2019].

Bilateral negotiations with two ASEAN Member States have already been completed and a free trade zone was established: the EU-Singapore (EUSFTA) in 2014 and Vietnam (EVFTA) in 2015. The ultimate objective of the European Union is to create a free trade zone with ASEAN.

ASEAN is the third largest EU trade partner outside the EU, after the US and China ( $€ 237.3$ billion in 2018). The European Union is the second largest trading partner for ASEAN after China, accounting for about $14 \%$ of trade. The EU is currently the largest investor in ASEAN Member States. In 2017, shares of foreign direct investment in ASEAN amounted to $€ 337$ billion, and ASEAN's investment in Europe increased to more than $€ 141$ billion. The EU mainly exports chemical products, cars and agricultural products to the Member States of the Association of Southeast Asia. The main imports from ASEAN to the EU are cars and transport equipment, agricultural products, textiles and clothing (see Figure 2).

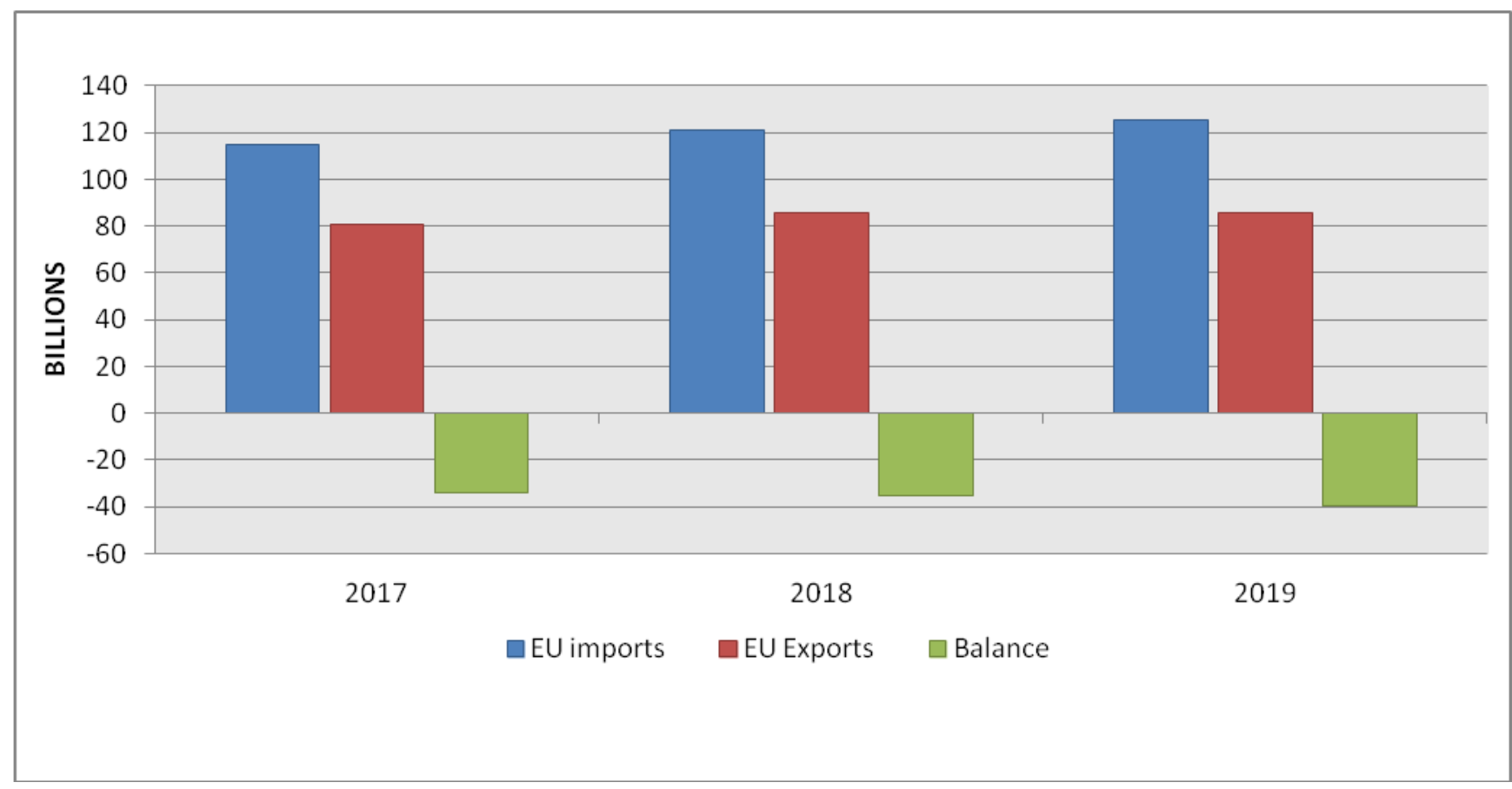

Figure 2. EU-ASEAN: trade in goods

Source: [European Commission, 2020]

Given that regionalization and globalization are the main trends in the current global competitive environment, and small ASEAN states, with the exception of Indonesia, can build up their economic and competitive force only through international and inter-union cooperation, comprehensive cooperation between the European Union and the Association of Southeast Asian Nations will help ASEAN find an effective model of integration and narrow disparities in economic development between Member States.

The two economic and competitive giants, such as the EU and the USMCA, interact in the format of bilateral relations, namely the European Union + USMCA member state. EU-US trade and investment relations affect not only their economies but also the world economy as a whole. The US and the EU are the largest trading partners for each other and represent the major trade and 
competitive relations between the actors of the global economy. In general, the US and EU economies account for about half of world GDP and almost a third of the world trade flows.

Given the scope and level of integration of the transatlantic economy, there is current interest in formalizing the structure underlying trade and competition relations between the United States and the European Union. Negotiations for the Transatlantic Trade and Investment Partnership (TTIP) were formally launched in 2013. However, following 15 rounds of negotiations, the talks were suspended at the end of 2016. This was in part due to the change of administration in the US, but TTIP negotiations had stalled even before the election of Donald Trump over contentious issues such as agriculture, public procurement and investment protection. Neither the US nor the EU has officially withdrawn from the TTIP negotiations. After a two-year hiatus, in October 2018, the Trump administration announced the resumption of negotiations on a trade agreement with the EU [M. Schneider-Petsinger, 2019].

The driving force of transatlantic integration is investment, which promotes growth and jobs on both sides of the Atlantic. Total US investment in the EU (the balance of EU-US foreign direct investment in 2018 was $€ 375.4$ trillion) is three times higher than in Asia, and EU investment in the US is around eight times the amount of EU investment in India and China together. It is estimated that a third of the trade across the Atlantic actually consists of intra-company transfers. The transatlantic relationship also defines the shape of the global economy as a whole. Either the EU or the US is the largest trade and investment partner for almost all other countries in the global economy [European Commission, 2020].

In 2019, exports of EU goods to the US amounted to $€ 384.4$ billion, while US exports to the EU amounted to $€ 232.0$ billion. The European Union exported $€ 179.4$ billion in services to the US, while the US exported $€ 196.2$ million in services to the EU in 2018 (see Figures 3 and 4).

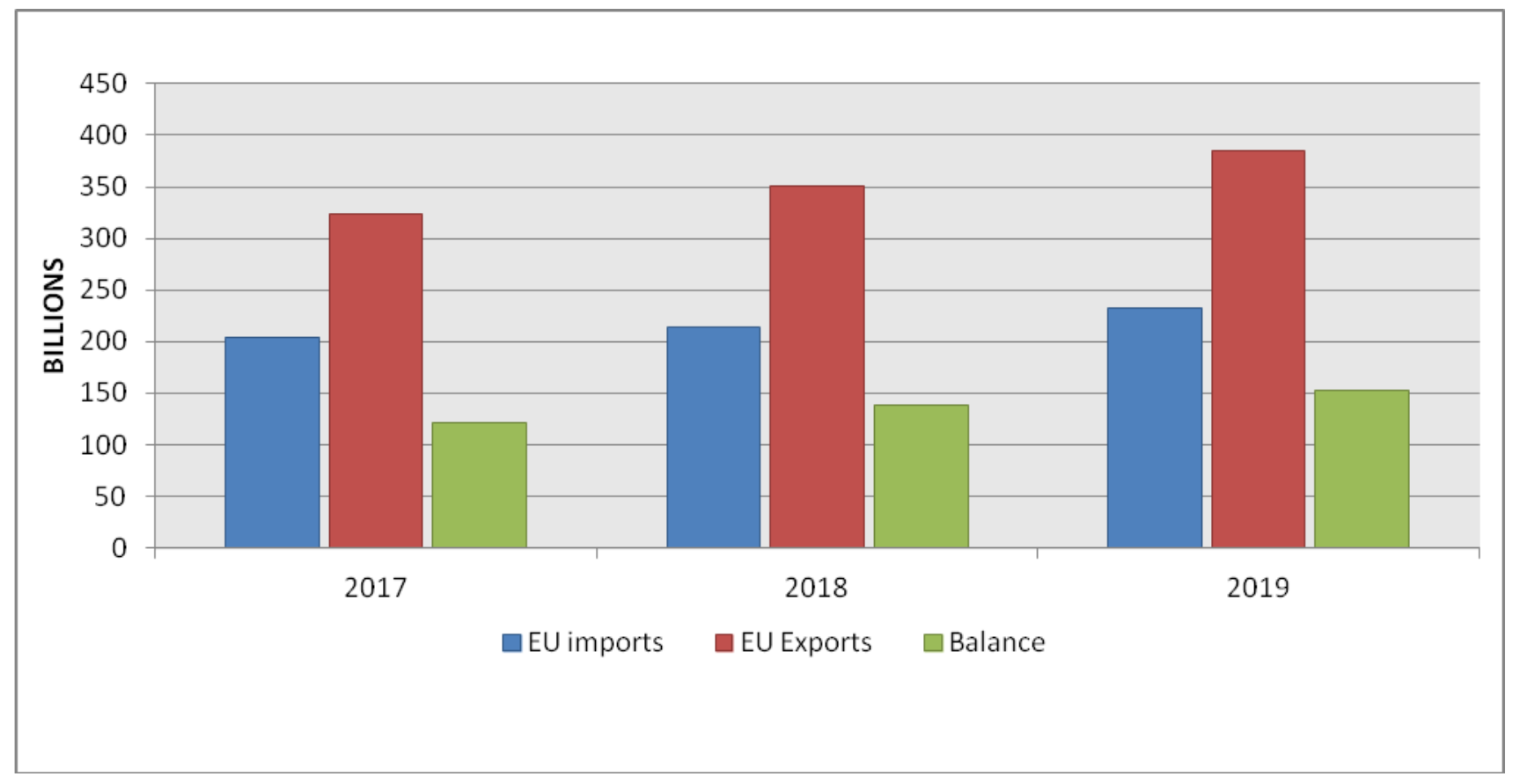

Figure 3. EU-USA: trade in goods

Source: [European Commission, 2020] 


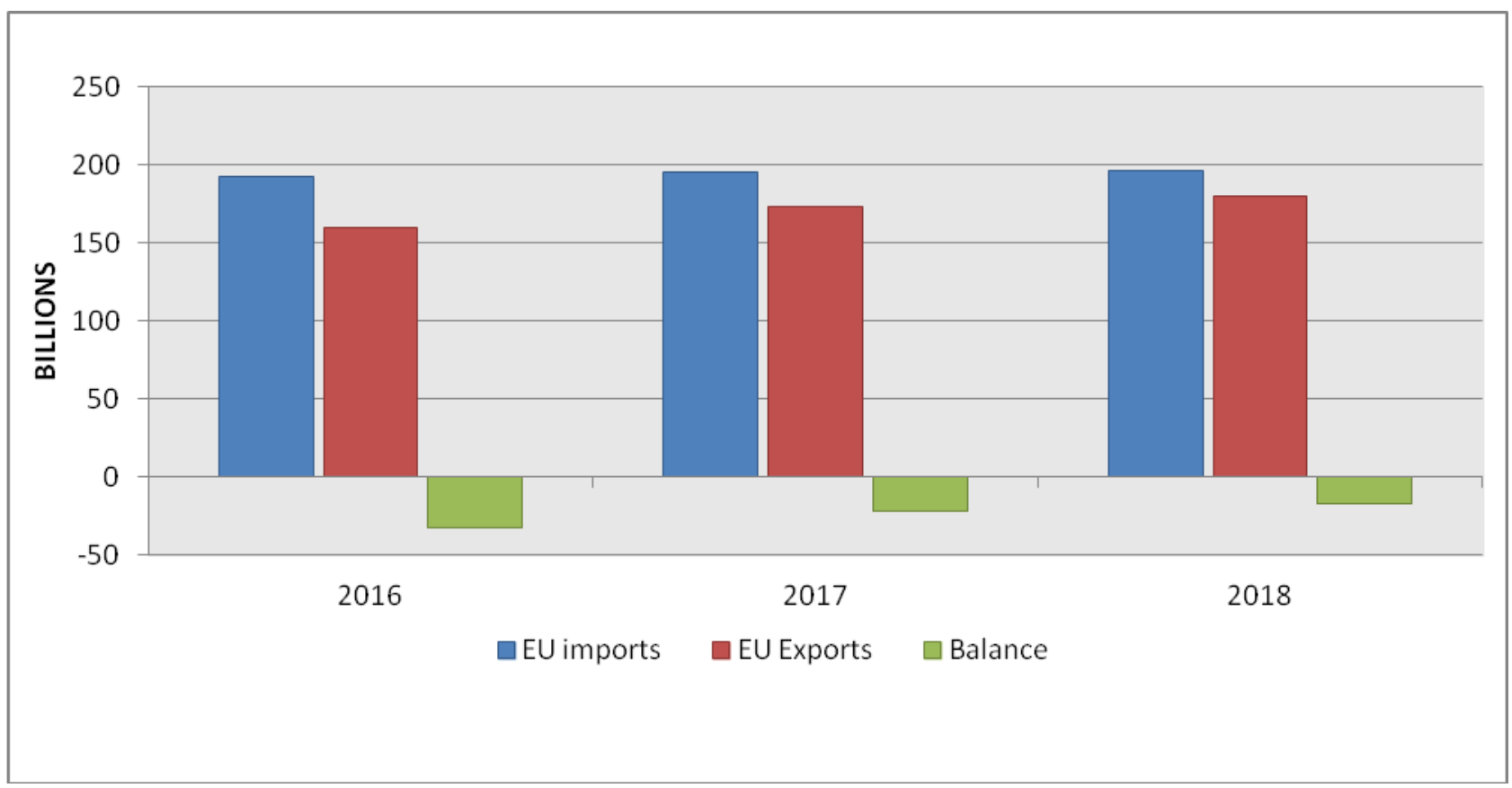

Figure 4. EU-USA: trade in services

Source: [European Commission, 2020]

Bilateral economic and competitive cooperation between the EU and the US in terms of mutual trade is unprecedented. Despite such large volumes of trade, the EU and the US face a number of trade and competition disputes.

Mexico was the first North American country to sign an economic partnership agreement with the European Union in 1997, which entered into force in 2000. In 2016, a dialogue on the modernization of this agreement began, and after four years of negotiations on new trade relations between the European Union and Mexico, they ended with a free trade agreement. Under this agreement, virtually all trade in goods between the EU and Mexico will be duty free.

"While most of our efforts have been focused lately on tackling the coronavirus crisis, we have also been working to advance our open and fair trade agenda. Openness, partnerships and cooperation will be even more essential as we rebuild our economies after this pandemic. Together with our Mexican partners, we share similar views and that our continued work could now come to fruition. This agreement will help both the EU and Mexico to support our respective economies and boost employment", said EU trade commissioner Phil Hogan [E. Wragg, 2020].

In 2018, the EU was Mexico's second biggest export market after the United States. The EU's key imports from Mexico are transport equipment, machinery and appliances, mineral products, and optical/photographic instruments. The EU was Mexico's third-largest source of imports in 2018, after the US and China. Key EU exports to Mexico include machinery and appliances, transport equipment, chemical products, and base metals. In services, the EU imports from Mexico mostly travel and transport services. EU services exports to Mexico consist mainly of business services, transport services, travel services, and telecommunications, computer and information services.

In 2019, exports of EU goods to Mexico amounted to $€ 37.6$ billion, while exports of Mexico to the EU amounted to $€ 24.3$ billion. The European Union exported $€ 11.6$ billion in services to Mexico, while Mexico exported $€ 5.5$ million in services to the EU in 2018 (see Figures 5 and 6). 


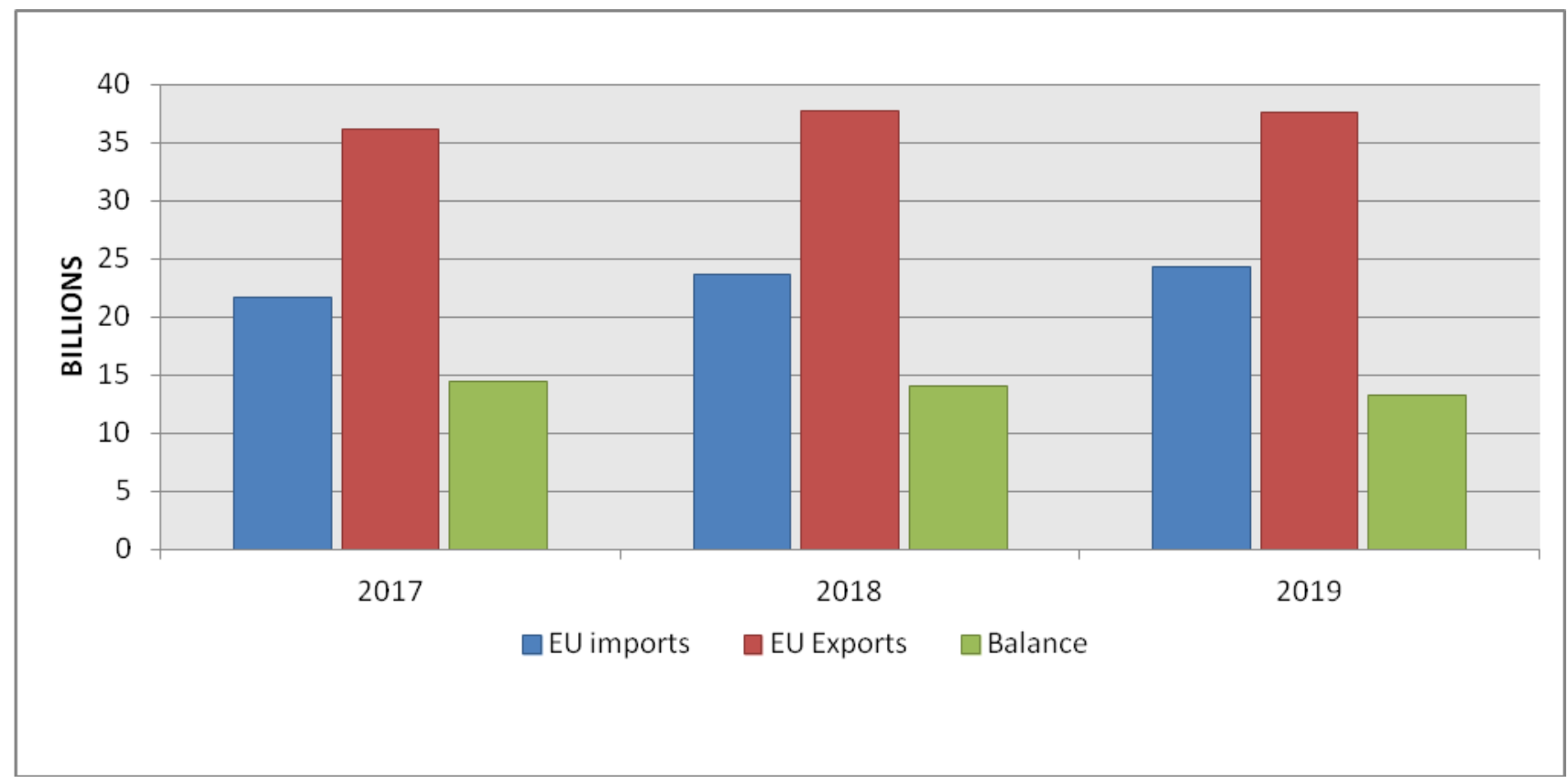

Figure 5. EU-Mexiko: trade in goods

Source: [European Commission, 2020]

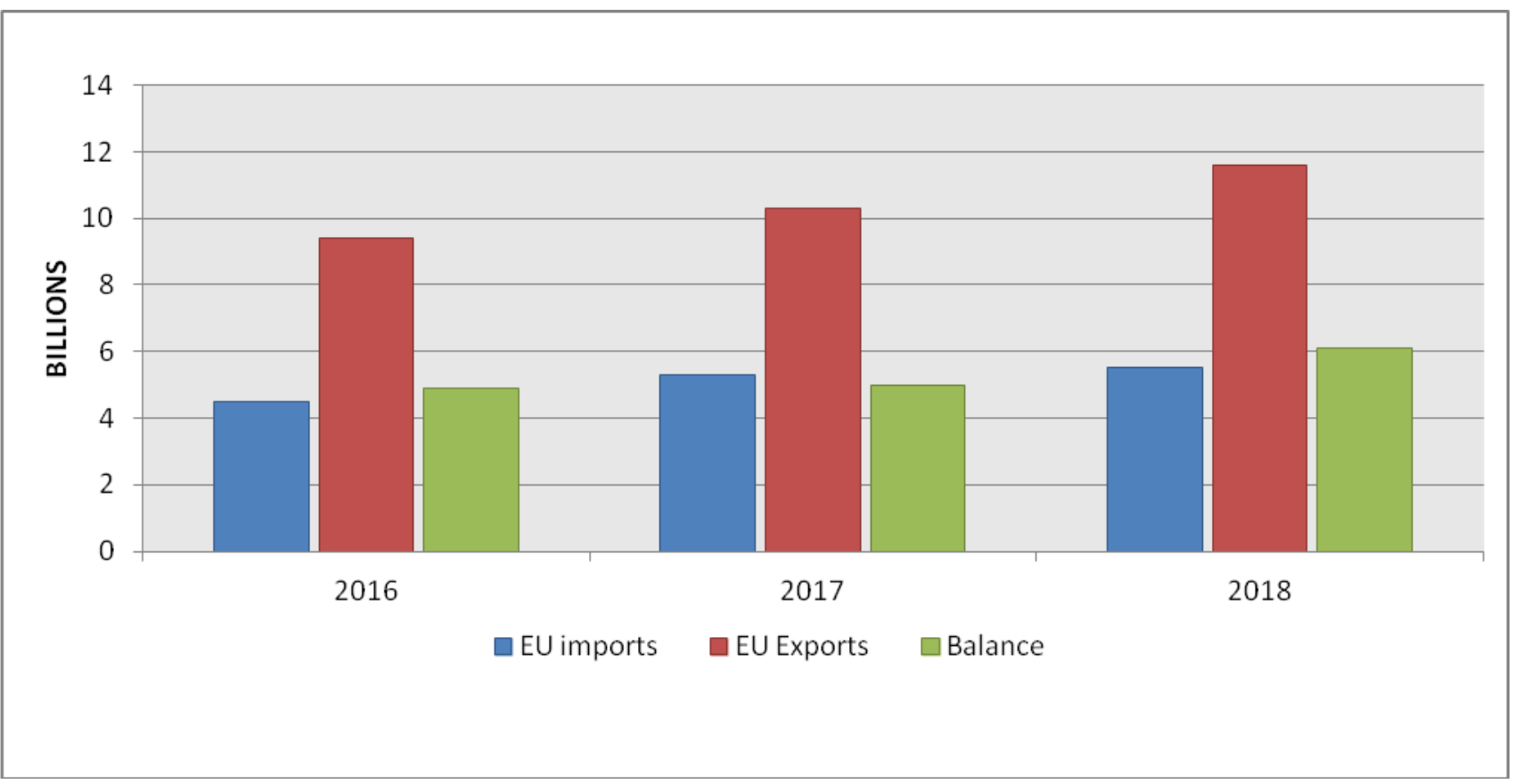

Figure 6. EU-Mexiko: trade in services

Source: [European Commission, 2020]

Negotiations on the free trade zone between the EU and Canada began in 2009, and in 2017 the EU-Canada Comprehensive Economic and Trade Agreement (CETA) entered into force. It provides for the abolition of $99 \%$ of customs tariffs and brings economic benefits primarily for small and medium-sized businesses, allowing duty-free export of almost all manufactured goods, reducing the time for customs control and making the movement of goods cheaper and faster.

The EU is Canada's second-biggest trading partner after the United States, accounting for $10 \%$ of its trade in goods with the world in 2018. Canada accounted for almost $2 \%$ of the EU's total external trade in goods in 2018. The products that the EU and Canada export to each other: 
machinery (25.6\% of EU exports to Canada and $24.3 \%$ of its imports); chemical and pharmaceutical products (16.2\% of EU exports and 9.1\% of its imports); transport equipment (15.6 $\%$ of EU exports and $7.0 \%$ of its imports). Trade in services between the two parties amounted to $€ 34.9$ billion in 2017 (services exported between Canada and the EU are transport, travel, insurance and communication services). In 2017 The EU exported $€ 14.4$ billion more in goods and services to Canada than it imported.

In 2019, exports of EU goods to Canada amounted to $€ 38.3$ billion, while Canadian exports to the EU was $€ 20.7$ billion. The European Union exported $€ 19.0$ billion in services to Canada; while Canada exported $€ 13.5$ million in services to the EU in 2018 (see Figures 7 and 8).

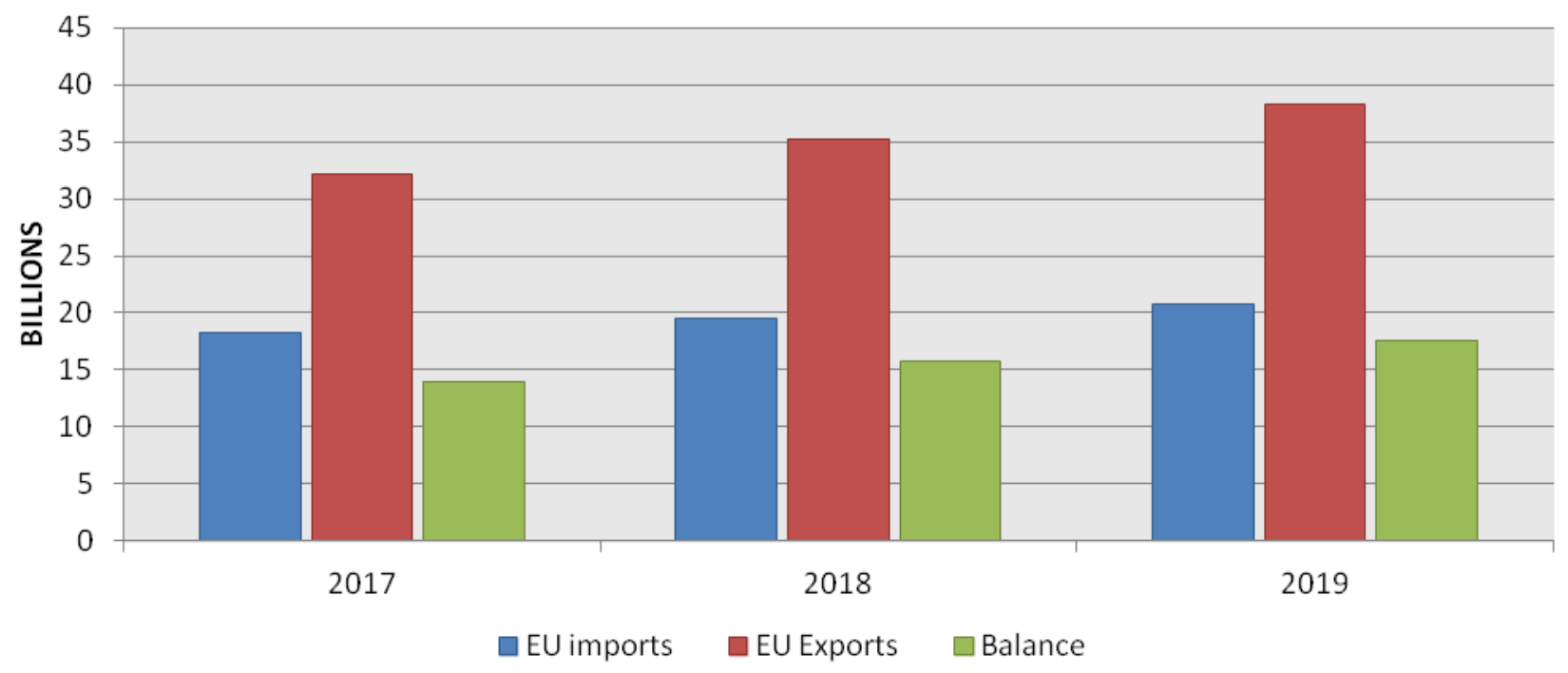

Figure 7. EU-Canada: trade in goods

Source: [European Commission, 2020]

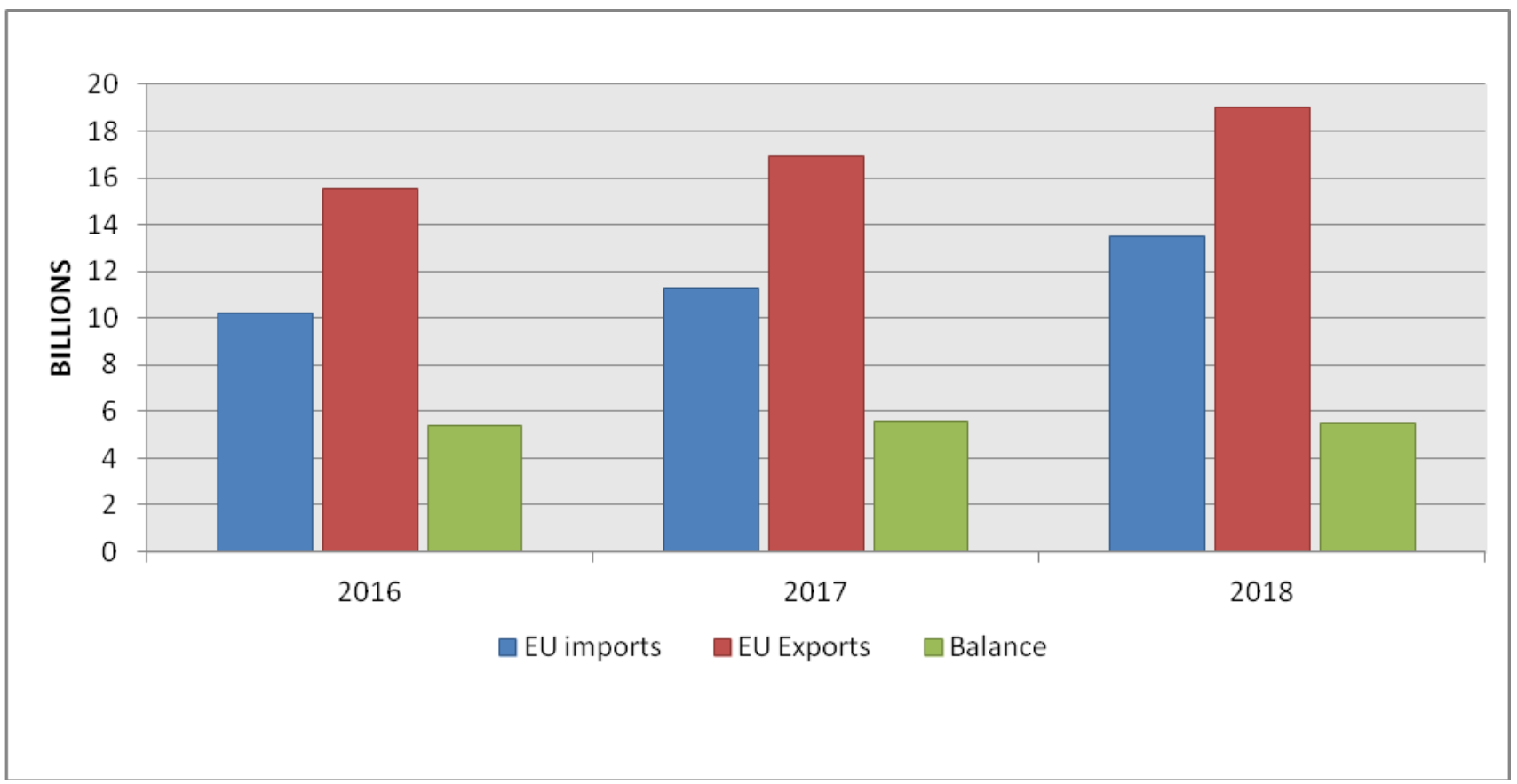

Figure 8. EU-Canada: trade in services

Source: [European Commission, 2020] 
Conclusion. Competitive positions of international integration groupings in the global economy are being strengthened due to the active development of economic and trade cooperation, not only within the grouping of Member States, but also in the parallel process of interaction with non-Member States and with international integration groupings. This process is based mainly on bilateral agreements and talks on the free trade zone, which involve interstate integration groupings, and not only individual states. This determines a new phenomenon of cooperation formalization between interstate integration groupings, namely the negotiation of a free trade zone between them. The position of any integration grouping is increasingly being determined not only by the internal potential and interaction between the Member States of the grouping, but also by the degree of economic and competitive cooperation, since it becomes apparent that the economies of the Member States of the integration grouping cannot be restricted by the grouping, but must develop their economic and competitive relations. Currently, trade and competitive convergence of interstate integration groupings leads to new forms and mechanisms of activities organization and as a result, the prospects for the free trade zones consolidation are emerging. Interstate integration groupings are being involved in the global trade and competitive environment through the intensification of their foreign economic relations, taking into account the special positions of Member States.

\section{References}

1. ASEAN Secretariat's Information Paper As February 2020. Rerieved from https://asean.org/storage/2020/06/Overview-of-ASEAN-EU-Relations-as-of-February-2020.pdf

2. Baert, F., Scaramagli, T. \& Soderbaum, F. (2014). Intersecting Interregionalism: Regions, Global Governance and the EU. Doi: 10.1007 / 978-94-007-7566-4

3. Baltensperger, M. \& Dadush, U. (2019). The European Union-Mercosur Free Trade Agreement: prospects and risks. Policy Contribution, 11. Retrieved from https://www.bruegel.org/wp-content/uploads/2019/09/PC-11_2019.pdf

4. European Commission. ASEAN. Trade picture. Retrieved from https://ec.europa.eu/trade/policy/countries-and-regions/regions/asean/

5. European Commission. Mercosur. Trade picture. Retrieved from https://ec.europa.eu/trade/policy/countries-and-regions/regions/mercosur/

6. European Commission. Trade picture EU and US. Retrieved from https://ec.europa.eu/trade/policy/countries-and-regions/countries/united-states/

7. EU and Mercosur reach agreement on trade. European Commission..Retrieved from https://ec.europa.eu/commission/presscorner/detail/en/IP_19_3396

8. EU-Mercosur Trade agreement, (2019). Retrieved from https://trade.ec.europa.eu/doclib/docs/2019/june/tradoc_157955.pdf

9. Felter, C., Renwick, D. \& Chatzky, A. (2019). Mercosur: South America's Fractious Trade Bloc. Council on Foreign Relations. Retrieved from https://www.cfr.org/backgrounder/mercosursouth-americas-fractious-trade-bloc

10. Hänngi, H., Roloff, R., \& Rüland, J. (2006). Interregionalism and International Relations. Oxon: Routledge. Doi: https://doi.org/10.4324/9780203008324

11. Ghiotto, L. \& Echaide, J. (2019). Analysis of the agreement between the European Union and the Mercosur. Retrieved from https://www.annacavazzini.eu/wp-content/uploads/2020/01/Study-onthe-EU-Mercosur-agreement-09.01.2020-1.pdf

12. Manservisi, S. \& Fontan, F. (2019). EU-ASEAN cooperation 1977-2019. Retrieved from http://www.asiapacificfarmersforum.net/wp-content/uploads/2019/05/EU-ASEAN-Blue-Book2019.pdf

13. Michalopoulos, S. (2019). EU farmers boss: "Devastating" Mercosur trade pact exposes Europe's double standards. Retrieved from https://www.euractiv.com/section/agriculturefood/news/eu-farmers-boss-devastating-mercosur-trade-pact-exposes-europes-double-standards/

14. Schneider-Petsinger, M. (2019). US-EU Trade Relations in the Trump Era Which Way Forward? Retrieved from https://www.chathamhouse.org/publication/us-eu-trade-relations-trumpera-which-way-forward/2019-03-08US-EUTradeRelations2.pdf 
15. Wragg, E. (2020). EU-Mexico trade deal jumps final hurdle. Retrieved from https://www.gtreview.com/news/europe/eu-mexico-trade-deal-jumps-final-hurdle/

16. Lay, Y. \& Lopez, L. (2008). Regionalism and Interregionalism in the ASEM context: Current Dynamic and Theoretical Approaches. Retrieved from https://www.files.ethz.ch/isn/103570/doc_asia_23.pdf 